\title{
Development and application of cereal mycelium supplements in food production
}

\author{
Oksana Blinova*, Aliya Trots, Natalya Prazdnichkova, and Ekaterina Alexandrova \\ Samara State Agrarian University, 446442 Kinel, Samara region, Russia
}

\begin{abstract}
Development of industrial technologies of production of protein products from plant materials is one of the main directions of increasing food products, improving nutritional and biological values. Protein supplements produced from grain flour enriched with mycelium are promising. When producing bread and pasts from wheat flour, the use of $3 \%$ wheat, oat, barley and millet flour enriched with mycelium is optimal. Quality values of yohurt drinks can be improved by adding $2 \%$ protein supplements based on oat and buckwheat.
\end{abstract}

\section{Introduction}

It is necessary to produce food products using functional ingredients, food supplements made from plant materials. The disadvantages of these supplements are their volume limitations, low functional and biological properties, limited domestic production resources and low organoleptic properties of the finished product. It is necessary to improve biological and functional properties of the product, reduce the cost of production by using non-expensive sources of domestic production. Currently, the volume of food products cannot satisfy the need for basic food components, especially food protein. According to experts, in Russia the average per capita protein deficit is $30 \%$.

The growing worldwide deficiency of protein requires new and unconventional protein sources. The production of highly nutritious food protein products (meat, dairy, cereals) with the addition of protein ingredients should be economical and effective.

The development of industrial technologies for the production of concentrated protein products from plant materials is one of the main directions of increasing food resources, improving nutritional quality and increasing the nutritional and biological value of food products [1].

Under the deficiency of dietary protein, one of the main areas of food biotechnology is the search for alternative sources of protein in resources of plant, microbiological and fungal origin [2].

In this regard, the use of food protein supplements for the production and enrichment of food is an important issue of great economic importance. Studying the consumer properties of food products from plant and animal raw materials containing a protein supplement based on grain flour enriched with champignon mycelium is of practical interest, and experimental studies on the effect of this supplement on the quality of various types of food products are of industrial importance.

The application of plant materials improves organoleptic and phisico-chemical parameters of bread [3-6], pasta [7-9] and yogurt products [10-12].

\section{Purpose}

The experimental justification includes the development and application of a protein supplement based on flour enriched with mycelium. The tasks of the study are as follows : 1) to determine quality of protein supplements based on flour enriched with mycelium; 2) to determine the optimal product impact on the dosage of the dietary protein supplement based on flour enriched with mycelium; 3) to optimize the recipe components. The object of research is food products containing protein supplements based on flour enriched with mycelium. The subject is a food protein supplement based on flour enriched with mycelium and the influence of the control of the supplement on quality of food products.

\section{Materials and methods}

A protein supplement was obtained from fruit bodies of dicotyledonous mushroom and soft wheat, buckwheat, millet, oats and barley enriched with dicotyledonous mycelium, as well as their mixtures. Grain was cleaned of impurities, washed, cooked for 30 minutes, and dried. Jars were sterilized for 2 hours at 1050 C. Grain was packaged in jars, covered with lids. Then the jars were placed in a container with water and boiled twice for two hours at a day interval. The substrate was sterilized, and most of the bacteria died. When boiling, the water should not get into the joars. The fermentation process was carried out; jars were placed into an oven at a temperature of $50 \ldots 550 \mathrm{C}$ for 30 hours. $10 \%$ of

\footnotetext{
* Corresponding author: Blinova_oks@ mail.ru
} 
mycelium was added into each jar. Jars were placed into a thermostat at a temperature of 18 ... 200C. Food supplements obtained from the fruit bodies of dicotyledonous champignon and grain enriched with mycelium were stored in dry, cool warehouses in undamaged closed jars.

When conducting research, wheat flour was used. It met the requirements of the Russian standard "Wheat flour. General technical conditions." Indicators of quality of pasta were determined in accordance with the Russian standard "Pasta. Rules and methods for determining quality." A yogurt drink with the use of a dietary protein supplement and without the use of a dietary protein supplement was studied by organoleptic (appearance, color, structure and texture, taste, smell and aroma) and physicochemical (acidity, mass fractions of fat and protein) indicators on the third, fifth and seventh days of storage. These indicators were determined according to generally accepted methods.

For the preparation of bread, an unpaired method of preparing dough was used. Bread production was carried out by a test laboratory baking method in accordance with the Russian standard "Baking wheat flour. The test bread baking method "with its subsequent evaluation according to indicators according to generally accepted methods. The main indicators of the quality of pasta were determined in accordance with the Russian standard "Pasta. Acceptance rules and methods for determining quality. " A yogurt drink with the use of a dietary protein supplement and without the use of a dietary protein supplement was investigated by organoleptic (appearance, color, structure and texture, taste, smell and aroma) and physicochemical (acidity, mass fraction of fat, mass fraction of protein) indicators moment of development; on the third, fifth and seventh day of storage. The determination of these indicators was carried out in accordance with the normative documentation according to generally accepted methods.

The enrichment of food products was carried out in the following areas: increasing the biological value when using a food supplement based on grain flour enriched with mycelium.

Currently, about 1.5 thousand tons of mycelium are produced per year using the surface fermentation method and 2 thousand tons - using the deep method. Organic substances of mycelium consist of carbohydrates and nitrogenous substances $\left(\begin{array}{llll}25 & \ldots & 30 \%\end{array}\right)$. In addition, mycelium contains free amino acids, other organic acids, fats, alcohols, phospholipids, enzymes, vitamins and other substances.

The use of components that give bread therapeutic and prophylactic properties allows us to solve the problem of prevention and treatment of diseases associated with a deficiency of certain substances. The use of food protein supplements favorably affects the consumer properties of bread, increases protein content. We studied the effect of a protein-based food supplement based on soft wheat flour, buckwheat, millet, oat and barley enriched with mycelium of champignon on the quality of bread. The supplement was added when kneading the dough in a dry form in the amount of $3 \%$.

The experimental scheme included six options: without the use of unconventional raw materials (control option) and with the use of a protein supplement based on soft wheat flour, buckwheat, millet, oats and barley enriched with mycelium in the amount of $3 \%$.

A large number of various yogurt drinks enriched with vitamins and various additives that improve the nutritional value have been developed. It is known that fermented milk products, which include a yogurt drink, are high-tech and convenient products for creating new types of functional nutrition for people of different age categories. We studied the effect of food protein supplements based on soft wheat flour, buckwheat, millet, oat and barley enriched with mycelium of champignon on the quality of a yogurt drink. The supplement was added in the amount of $2 \%$ of the mass of the main raw material. Then, the intensive mixing was carried out.

All the experiments were carried 3-4 times. The tables show more data for each experiment. Only those results which can be reproduced in each experiment are discussed. Deviations did not exceed 1-3\%.

\section{Results}

To produce mushroom flour, dried fruit bodies of champignon were used. They met the requirements of TU 61 RF 01-172-94 "Dried mushrooms. Technical conditions." Appearance - the plates are elastic, slightly fragile, gray; taste and smell - typical of dried mushrooms, without extraneous smell. The chemical composition of grain used for enrichment with mycelium is shown in Table 1.

Table 1. The chemical composition of grain used for the production of protein supplements

\begin{tabular}{|l|c|c|c|c|c|c|}
\hline \multirow{2}{*}{ Grain } & \multicolumn{5}{|c|}{ Mass fraction, \% } & \multirow{2}{*}{ NFEF, \% } \\
\cline { 2 - 6 } & dry matter & crude protein & crude fiber & crude fat & crude ash & \\
\hline wheat & 88.50 & 12.98 & 4.92 & 3.38 & 6.47 & 72.25 \\
\hline barley & 88.94 & 12.40 & 7.59 & 3.45 & 5.85 & 70.71 \\
\hline oats & 88.04 & 14.43 & 8.81 & 3.90 & 4.30 & 68.56 \\
\hline millet & 88.31 & 9.69 & 8.10 & 4.12 & 8.21 & 69.88 \\
\hline
\end{tabular}

The dry matter content was $88.04 \ldots 88.94 \%$. The largest amount of crude protein in dry matter was observed in oat grain $(14.43 \%)$, the lowest value was observed in millet grain $(9.69 \%)$. The content of the mass fraction of fiber in wheat grains was $4.92 \%$; in barley, oats and millet grains, it was $7.59-8.81 \%$. The mass fraction of fat was $3.38-4.12 \%$, and the content of crude ash was $4.30-8.21 \%$.

Mycelium has a uniform and crumbly structure, without wet and compacted areas, spots ; mycelium had a typical smell. The substrate for the production of mycelium was wheat, oats, barley and millet grains. The 
appearance of the grain mycelium was as follows: grain with mycelium had a uniform and crumbly structure. High-quality mycelium covered each grain; mycelium penetrated into the grain. The color is white without spots of green, black, yellow and other colors. The smell is pleasant mushroom, not sour and not musty. The mass fraction of moisture was $43.0 \%$ in soft wheat grain, $43.0 \%$ in oat grain, $42.7 \%$ in barley grain, and $43.0 \%$ in millet grain. The concentration of hydrogen ions ranged from 6.1 to $6.3 \mathrm{pH}$ units.

The nutritional protein supplements based on cultivated mushrooms and a mixture of grain mycelium were a homogeneous dry powder, without impurities, insoluble in water. The color of food protein supplements corresponded to the color of grain used : light gray or light brown.

The protein supplement had a gray color with a brown tint. The smell was typical of this raw material, not musty and not moldy. The supplement had a pronounced pleasant mushroom smell. The taste of food protein supplements was powdery, without extraneous flavors, not sour, not bitter.

The mass fraction of moisture was 8.05 ... 17.88\%. The acidity depending on the raw materials used was 2.6-3.4 pH units. The highest value of this indicator was in the supplement produced from $100 \%$ mushroom flour and additives from a mixture of $50 \%$ mushroom and $50 \%$ soft wheat flour enriched with mycelium (3.4 and $3.3 \mathrm{pH}$ units, respectively (Table. 2).

During the studies, water-binding and fat-binding abilities of food additives were determined. Depending on the raw materials used: water-binding ability was 700 ... 800\%; fat-binding ability was $190 \ldots 230 \%$. Thus, the effective ratio of water to food protein supplements is 1 : 7 ... 1: 8. The mass fraction of dry matter was $87.12 \ldots$ $91.95 \%$ (Table 3).

Table 2. Physico-chemical and functional technological indicators of quality of a food protein supplement based on bicuspid champignon and a mixture of grain mycelium

\begin{tabular}{|l|c|c|c|c|}
\hline \multicolumn{1}{|c|}{ Nutritional Protein Supplements } & $\begin{array}{c}\text { Moisture } \\
\text { content, } \%\end{array}$ & $\begin{array}{c}\text { Acidity, } \\
\text { degrees }\end{array}$ & $\begin{array}{c}\text { Water binding } \\
\text { ability, } \%\end{array}$ & $\begin{array}{c}\text { Fat-binding } \\
\text { ability, } \%\end{array}$ \\
\hline champignon flour & 17.88 & 3.4 & 700 & 230 \\
\hline $\begin{array}{l}\text { soft wheat flour enriched with mycelium of bicuspid } \\
\text { champignon }\end{array}$ & 8.05 & 2.8 & 800 & 200 \\
\hline oat flour enriched with mycelium of bicuspid champignon & 8.92 & 2.7 & 800 & 200 \\
\hline barley flour enriched with mycelium of bicuspid champignon & 10.77 & 2.7 & 800 & 200 \\
\hline millet flour enriched with mycelium of bicuspid champignon & 8.52 & 2.6 & 750 & 190 \\
\hline $\begin{array}{l}\text { mushroom flour and soft wheat flour enriched with mycelium of } \\
\text { bicuspid champignon }\end{array}$ & 12.88 & 3.3 & 770 & 210 \\
\hline mushroom flour and oat flour enriched with mycelium & 12.26 & 3.1 & 750 & 210 \\
\hline mushroom flour and barley flour enriched with mycelium & 12.19 & 3.1 & 750 & 210 \\
\hline mushroom flour millet flour enriched with mycelium & 12.89 & 3.0 & 750 & 200 \\
\hline $\begin{array}{l}\text { mushroom flour, wheat flour enriched with mycelium, barley } \\
\text { flour enriched with mycelium, millet flour enriched with } \\
\text { mycelium }\end{array}$ & 10.62 & 2.8 & 700 & 200 \\
\hline
\end{tabular}

Table 3. The chemical composition of food protein supplements based on bicuspid champignon mushrooms and a mixture of grain mycelium

\begin{tabular}{|c|c|c|c|c|c|c|}
\hline \multirow{2}{*}{ Nutritional Protein Supplements } & \multicolumn{5}{|c|}{ Mass fraction, $\%$} & \multirow{2}{*}{$\begin{array}{c}\text { NFEF, } \\
\%\end{array}$} \\
\hline & $\begin{array}{c}\text { dry } \\
\text { matter }\end{array}$ & $\begin{array}{l}\text { crude } \\
\text { protein }\end{array}$ & $\begin{array}{l}\text { crude } \\
\text { fiber }\end{array}$ & $\begin{array}{l}\text { crude } \\
\text { fat }\end{array}$ & $\begin{array}{l}\text { crude } \\
\text { ash }\end{array}$ & \\
\hline champignon flour & 82.12 & 24.94 & 6.76 & 0.70 & 8.11 & 41.61 \\
\hline $\begin{array}{l}\text { soft wheat flour enriched with mycelium of bicuspid } \\
\text { champignon }\end{array}$ & 91.95 & 16.08 & 3.25 & 3.92 & 3.78 & 64.92 \\
\hline oat flour enriched with mycelium of bicuspid champignon & 91.08 & 15.21 & 7.84 & 4.81 & 3.14 & 60.08 \\
\hline barley flour enriched with mycelium of bicuspid champignon & 89.23 & 15.95 & 2.43 & 2.98 & 2.77 & 65.10 \\
\hline millet flour enriched with mycelium of bicuspid champignon & 91.48 & 10.79 & 6.49 & 3.63 & 4.45 & 66.12 \\
\hline $\begin{array}{l}\text { mushroom flour and soft wheat flour enriched with mycelium } \\
\text { of bicuspid champignon }\end{array}$ & 87.12 & 25.33 & 6.43 & 0.16 & 14.19 & 53.89 \\
\hline mushroom flour and oat flour enriched with mycelium & 87.74 & 26.75 & 10.25 & 0.56 & 13.53 & 48.91 \\
\hline mushroom flour and barley flour enriched with mycelium & 87.81 & 18.99 & 6.13 & 2.28 & 20.02 & 52.58 \\
\hline mushroom flour millet flour enriched with mycelium & 87.11 & 25.34 & 7.79 & 0.39 & 12.64 & 53.84 \\
\hline $\begin{array}{l}\text { mushroom flour, wheat flour enriched with mycelium, barley } \\
\text { flour enriched with mycelium, millet flour enriched with } \\
\text { mycelium }\end{array}$ & 89.38 & 18.59 & 8.04 & 1.76 & 13.87 & 57.71 \\
\hline
\end{tabular}

The mass fraction of protein varied from 10.79 to $26.75 \%$ and depended on the raw materials used. The content of the mass fraction of crude fiber, crude fat and ash also varied according to the options of the experiment depending on the type and amount of components included in the composition of food protein supplements. 
The appearance of wheat flour bread with a dietary protein supplement based on grain flour enriched with mycelium was slightly different in the experimental variants. Bread from wheat flour without protein-based dietary supplement had a flat surface, the crust color was light brown.

The crust of bread made from wheat flour using a food supplement based on white wheat, oat, barley and millet grain was convex (5 points), and that of bread from buckwheat grain was slightly convex (3 points). The surface of the crust of bread produced from wheat flour was flat, except for bread produced with the addition of flour from buckwheat enriched with mycelium. The surface was cracked ( 2 points). The color of the crust varied from light brown (4 points) to brown with a ruddy tint (5 points).

The use of a food-grade protein supplement had a significant impact on the characteristics of white wheat bread crumb. The color of the bread crumb changed depending on the type of additives. Bread from wheat flour had a white crumb color (5 points). Bread from wheat flour with the addition of wheat, barley, oats and millet flour had a white color of the crumb with a yellowish tint (5 points). Bread from wheat flour with soft wheat, barley and millet flour had a small, openwork, uniform, thin-walled crumb structure (5 points). The use of an additive from oat and buckwheat grains resulted in the formation of a fine, thin-walled, uneven crumb structure (4 points). The elasticity of the crumb of bread from wheat flour and bread with the addition of flour from soft wheat, barley, oats and millet enriched with mycelium was soft, silky, it easily restored the original structure (5 points). The finished product from wheat flour with buckwheat flour enriched with mycelium had a soft tender crumb (4 points).

The taste of bread from wheat flour with the addition of a food supplement was typical of this type of bread with a taste of the component under study.

The average bakery score for bread made from wheat flour was 4.9 points. The highest average score was for bread from wheat flour with the addition of soft wheat and millet flour enriched with mycelium was 5.0 points. The smallest score was for bread produced with the addition of a food protein supplement from buckwheat grain (3.1 points)

The volumetric yield of bread ranged from 460 to $520 \mathrm{~cm}^{3}$. The highest value of this indicator was obtained for bread from wheat flour with the use of food protein supplements based on millet flour enriched with mycelium $\left(260 \mathrm{~cm}^{3}\right)$. The porosity of bread from wheat flour increased when using protein supplements. The acidity of bread from wheat flour was 2.4-3 degrees (Table 4).

The mass fraction of crude protein was $17.51 \ldots$ $18.50 \%$. The mass fraction of crude fat was $1.60 \ldots$ $2.00 \%$, and the mass fraction of fiber was $0.87 \ldots 2.66 \%$ (Table 5).

Table 4. Physico-chemical indicators of quality of bread with supplements based on flour enriched with mycelium of champignon bicuspid

\begin{tabular}{|l|c|c|c|c|}
\hline \multicolumn{1}{|c|}{ Options } & $\begin{array}{c}\text { Volume of bread, } \\
\mathrm{cm}^{3} / 100 \mathrm{~g}\end{array}$ & $\begin{array}{c}\text { Crumb } \\
\text { porosity, } \%\end{array}$ & Moisture, \% & $\begin{array}{c}\text { Acidity, } \\
\text { degrees }\end{array}$ \\
\hline Wheat flour bread (control) & 240 & 74.1 & 30.66 & 2.4 \\
\hline $\begin{array}{l}\text { Wheat flour bread with a 3\% food protein supplement based } \\
\text { on soft wheat grain }\end{array}$ & 255 & 78.6 & 30.03 & 3.0 \\
\hline $\begin{array}{l}\text { Wheat flour bread with a 3\% food protein supplement based } \\
\text { on oat grain }\end{array}$ & 250 & 75.2 & 31.19 & 2.8 \\
\hline $\begin{array}{l}\text { Wheat flour bread with a 3\% food protein supplement based } \\
\text { on barley grain }\end{array}$ & 255 & 75.9 & 32.00 & 2.8 \\
\hline $\begin{array}{l}\text { Wheat flour bread with a 3\% food protein supplement based } \\
\text { on millet grain }\end{array}$ & 260 & 78.5 & 32.07 & 2.6 \\
\hline $\begin{array}{l}\text { Wheat flour bread with a 3\% food protein supplement based } \\
\text { on buckwheat grain }\end{array}$ & 230 & 74.5 & 30.21 & 2.8 \\
\hline
\end{tabular}

Table 5. The chemical composition of bread with supplements based on grain flour enriched with mycelium of champignon bicuspid

\begin{tabular}{|c|c|c|c|c|c|c|}
\hline \multirow[b]{2}{*}{ Options } & \multicolumn{5}{|c|}{ Mass fraction, $\%$} & \multirow[b]{2}{*}{ NFEF, $\%$} \\
\hline & $\begin{array}{c}\text { dry } \\
\text { matter }\end{array}$ & $\begin{array}{l}\text { crude } \\
\text { protein }\end{array}$ & $\begin{array}{l}\text { crude } \\
\text { fiber }\end{array}$ & $\begin{array}{c}\text { crude } \\
\text { fat }\end{array}$ & $\begin{array}{l}\text { crude } \\
\text { ash }\end{array}$ & \\
\hline Wheat flour bread (control) & 69.34 & 17.51 & 0.87 & 1.68 & 11.17 & 68.77 \\
\hline $\begin{array}{l}\text { Wheat flour bread with a } 3 \% \text { food protein supplement based } \\
\text { on soft wheat grain }\end{array}$ & 69.97 & 18.50 & 1.08 & 1.60 & 11.80 & 67.02 \\
\hline $\begin{array}{l}\text { Wheat flour bread with a } 3 \% \text { food protein supplement based } \\
\text { on oat grain }\end{array}$ & 68.10 & 18.14 & 2.66 & 1.63 & 14.24 & 63.33 \\
\hline $\begin{array}{l}\text { Wheat flour bread with a } 3 \% \text { food protein supplement based } \\
\text { on barley grain }\end{array}$ & 68.00 & 18.27 & 1.04 & 1.86 & 11.22 & 67.61 \\
\hline $\begin{array}{l}\text { Wheat flour bread with a } 3 \% \text { food protein supplement based } \\
\text { on millet grain }\end{array}$ & 67.93 & 18.25 & 0.97 & 2.00 & 9.13 & 69.65 \\
\hline $\begin{array}{l}\text { Wheat flour bread with a } 3 \% \text { food protein supplement based } \\
\text { on buckwheat grain }\end{array}$ & 69.79 & 17.90 & 1.19 & 1.70 & 10.66 & 68.55 \\
\hline
\end{tabular}


The pasta had no odor and taste. After cooking, products from wheat flour without additives and with food protein supplements based on flour from grain enriched with mycelium did not stick together.

The highest score were obtained for products manufactured according to the traditional technology (35 points) and products with additives based on soft wheat and barley grain (34 points). Physico-chemical quality indicators of pasta produced from wheat flour using mycelium are presented in Table 6.

Table 6. Physico-chemical quality parameters of pasta with supplements based on flour enriched with mycelium of champignon bicuspid

\begin{tabular}{|l|c|c|c|c|c|c|}
\hline \multirow{2}{*}{ Parameter } & \multicolumn{6}{|c|}{ Pasta } \\
\cline { 2 - 7 } & \multirow{2}{*}{ Control } & \multicolumn{6}{|c|}{\begin{tabular}{c} 
with flour-based supplements \\
\cline { 3 - 7 }
\end{tabular}} & & 7.9 & 8.0 & 8.0 & 8.0 & 7.9 & 8.0 \\
\hline Humidity, \% & 2.8 & 3.3 & 3.1 & 3.3 & 3.0 & 3.0 \\
\hline Acidity, degrees & 0.00 & 0.00 & 0.00 & 0.00 & 0.00 & 0.00 \\
\hline $\begin{array}{l}\text { Metallomagnetic impurity, mg } \\
\text { per 1 kg of product }\end{array}$ & 7 & 7 & 9 & 7 & 10 & 8 \\
\hline Cooking time, min & 100.0 & 100.0 & 100.0 & 100.0 & 100.0 & 100.0 \\
\hline Preservation of the shape, \% & 5.4 & 5.4 & 5.6 & 4.7 & 5.3 & 5.7 \\
\hline Dry matter in cooking water, \% & 5.4 & $\begin{array}{c}3 \% \\
\text { mittel }\end{array}$ & \\
\hline
\end{tabular}

The humidity of pasta made from wheat flour was $7.9 \ldots 8.0 \%$. When using a food additive, the acidity of products increased by $0.2 \ldots 0.5$ degrees. The duration of cooking depended on the type of additives used. Food preservation was $100.0 \%$. The transfer of solids into cooking water was $4.7 \ldots 5.7 \%$.

A yoghurt drink with a food protein supplement based on grain enriched with mycelium differed in color, taste and consistency. The results of organoleptic evaluation showed that the control sample and the samples with the use of food protein supplements had a uniform consistency. The color of the control drink was milky white, uniform. Samples with a protein supplement were light cream or cream. The control yogurt drink had a milky white color and a pure sourmilk moderately sweet taste. Yoghurt drinks with the use of a protein were light cream with inclusions of the supplement. A yoghurt drink produced using a dietary protein supplement based on millet flour enriched with mycelium and a yogurt drink produced using a protein supplement based on buckwheat flour enriched with mycelium were cream. The consistency of the control yogurt drink was homogeneous, moderately viscous, creamy, with a broken clot. The product with a protein supplement was homogeneous, moderately viscous, creamy, with a broken clot. The yoghurt drink with a protein supplement based on barley flour enriched with mycelium was more viscous.

Table 7. Physico-chemical indicators of quality of a yogurt drink depending on the use of supplements based on flour from grain enriched with mycelium of double-champignon champignon

\begin{tabular}{|c|c|c|c|c|c|c|}
\hline \multirow[b]{2}{*}{ yogurt drink } & \multirow[b]{2}{*}{$\begin{array}{l}\text { Mass } \\
\text { fraction of } \\
\text { protein, } \%\end{array}$} & \multirow[b]{2}{*}{$\begin{array}{l}\text { Mass } \\
\text { fraction of } \\
\text { fat, } \%\end{array}$} & \multicolumn{4}{|c|}{ Accidity, ${ }^{\circ} \mathrm{T}$} \\
\hline & & & $\begin{array}{l}\text { at the time } \\
\text { of } \\
\text { production }\end{array}$ & $\begin{array}{l}\text { on the } \\
\text { 3rd day }\end{array}$ & $\begin{array}{l}\text { on the } \\
5 \text { th day }\end{array}$ & $\begin{array}{l}\text { on the } \\
7 \text { th day }\end{array}$ \\
\hline control & 3.44 & 3.20 & 94 & 96 & 99 & 108 \\
\hline $\begin{array}{l}\text { with food protein supplements based on wheat } \\
\text { flour enriched with mycelium bicuspid } \\
\text { champignon }\end{array}$ & 3.32 & 3.20 & 94 & 98 & 102 & 110 \\
\hline $\begin{array}{l}\text { with food protein supplements based on oat flour } \\
\text { enriched with mycelium bicuspid champignon }\end{array}$ & 3.52 & 3.25 & 94 & 100 & 110 & 118 \\
\hline $\begin{array}{l}\text { with food protein supplements based on barley } \\
\text { flour enriched with mycelium bicuspid } \\
\text { champignon }\end{array}$ & 3.48 & 3.30 & 94 & 102 & 110 & 118 \\
\hline $\begin{array}{l}\text { with food protein supplements based on mittel } \\
\text { flour enriched with mycelium bicuspid } \\
\text { champignon }\end{array}$ & 3.49 & 3.25 & 94 & 98 & 108 & 118 \\
\hline $\begin{array}{l}\text { with food protein supplements based on } \\
\text { buckwheat flour enriched with mycelium } \\
\text { bicuspid champignon }\end{array}$ & 3.69 & 3.20 & 94 & 100 & 106 & 115 \\
\hline
\end{tabular}

On the third day of storage, no changes in color, smell, taste and aroma were found. On the fifth day of storage, the control yoghurt drink had a taste of

increasing acidity. On the following days of storage, no changes in color, smell, taste, and aroma were found in 
the control sample and the yoghurt drink with a food protein supplement.

The mass fraction of protein was $3.32 \ldots 3.69 \%$. The mass fraction of fat was $3.20 \ldots 3.30 \%$ (table. 7). The acidity of the yogurt drink was $94^{\circ} \mathrm{T}$, on the 3rd day $96 \ldots 102^{\circ} \mathrm{T}$, on the 5 th day $-99 \ldots 110^{\circ} \mathrm{T}$. On the 7 th day, acidity increased up to $108 \ldots 118^{\circ} \mathrm{T}$. On the seventh day, acidity increases within the norm.

The tasting results showed that the highest number of points was given to the yogurt drink produced without the use of a dietary protein supplement ( 8.2 points) and with the use of a protein supplement based on barley and buckwheat flour enriched with mycelium of champignon (8.1 and 8.3 points, respectively).

\section{Discussion}

The use of protein products requires new approaches and solutions, revision of the assortment, formulations and technologies, ideas about quality criteria and the nutritional value. The development and implementation of new food technologies aimed at the production of food products with a high biological value taking into account the needs of various social, professional and age groups of the population, including medical and preventive products, are promising. A successful solution to this problem is the use of plant resources, namely wild and cultivated mushrooms grown in the conditions of Samara region, as well as grains enriched with mycelium of champignon.

In general, the nutritional supplements have good organoleptic, functional and technological quality indicators and a high protein content.

Comparison of the chemical composition of soft wheat flour from mushrooms and wheat flour showed that protein content in mushroom flour is more by 12.44 and $14.64 \%$, fat - by 12.44 and $14.64 \%$ and ash - by 6.41 and $7.61 \%$, compared with soft wheat flour. The supplement contains $3.1 \%$ more protein, $0.54 \%$ more fat, $1.67 \%$ less fiber and $2.69 \%$ less ash. The content of the mass fraction of protein in barley flour enriched with mycelium is $3.55 \%$ higher than in barley flour. The content of the mass fraction of fat, fiber and ash in this food supplement is less in comparison with barley grain by $0.47 ; 5.16$ and $3.08 \%$, respectively.

Comparing the chemical composition of oat grain and flour from oat grain enriched with mycelium, it can be seen that the content of the mass fraction of protein in the food protein supplement is $0.78 \%$ higher than in oat grain. A protein supplement based on millet flour enriched with mycelium contains more protein than millet flour by $1.1 \%$.

The amount of protein in wheat flour enriched with mycelium is $25.33 \%$, in oat flour enriched with mycelium is $26.75 \%$ and in millet flour enriched with mycelium is $25.34 \%$. The largest amount of fiber was observed in oat flour enriched with mycelium (10.25\%). The highest content of the mass fraction of ash was observed in barley flour with mycelium $(20.02 \%)$.

The use of a protein supplement based on wheat, barley and millet flour enriched with mycelium in the amount of $3 \%$ improves quality indicators of wheat bread and increases the content of crude protein. Bread has a pleasant taste and aroma, normal volume and porosity.

The protein supplements had a significant impact on the appearance and characteristics of wheat flour pasta. With an increase in the amount of food protein supplements in pasta made from wheat flour, the protein content increased.

The yogurt drink produced using a protein supplement based on barley flour enriched with mycelium and the yogurt drink produced using food protein supplements based on buckwheat flour enriched with mycelium had the best organoleptic and physicochemical characteristics. These samples had a pleasant smell, harmonious taste ; no changes in the organoleptic indicators were observed during their storage ; physicochemical parameters were within the norm.

\section{Conclusion}

Promising supplements are protein supplements based on cereal flour enriched with mycelium of champignon.

Protein supplements produced from wheat, oat, barley and mittel flour enriched with mycelium in the amount of $3 \%$ improve bread quality.

When using non-traditional raw materials for pasta production, wheat and barley flour supplements enriched with mycelium can be used in the amount of $3 \%$. This improves consumer properties of pasta.

When using a protein supplement in the production of yoghurt drinks, the best effect is achieved when using barley and buckwheat flour enriched with mycelium in the amount of $2 \%$. These recommendations will allow you to produce a product with the best consumer properties.

\section{References}

1. P. Gélinas, C. David, Encyclopedia of Food Grains 4, 154-161 (2016)

2. X. Lu, M. A. Brennan, L. Serventi, J. Liu, C. S. Brennan, Food Chemistry 64, 199-209 (2018)

3. L. Tebben, Y. Shen, Y. Li, Trends in Food Science \& Technology 81, 10-24 (2018)

4. L. B. Fendri, F. Chaari, M. Maaloul, F. Kallel, D. Ghribi-Ay, LWT 73, 584-591 (2016)

5. M. Sajdakowska, J. Gębski, S. Żakowska-Biemans, M. Jeżewska-Zychowicz, Public Health 167, 78-87 (2019)

6. R. Coda, J. Varis, M. Verni, C. G. Rizzello, K. Katina, LWT - Food Science and Technology 82, 296-302 (2017)

7. R. Ciccoritti, F. Nocente, D. Sgrulletta, L. Gazza, LWT 101, 10-16 (2019)

8. S. Spinelli, L. Padalino, C. Costa, M. A. Del, A. Conte, J. of Cleaner Production 215, 985-991 (2019)

9. V. K. R. Surasani, A. Singh, A. Gupta, S. Sharma, LWT 111, 443-448 (2019) 
10. K. Das, R. Choudhary, K. A. Thompson-Witrick, LWT 108, 69-80 (2019)

11. E. Mohammadi-Gouraji, S. Soleimanian-Zad, M. Ghiaci, LWT 102, 230-236 (2019)
12. N. Tomic, B. Dojnov, J. Miocinovic, I. Tomasevic, Z. Vujcic, LWT 80, 59-66 (2017) 